Article

\title{
An Exploratory Study of the Mechanism of Sustainable Value Creation in the Luxury Fashion Industry
}

\author{
Yefei Yang ${ }^{1, *}$, Han Han $^{2}$ and Peter K. C. Lee ${ }^{3}$ \\ 1 Logistics Management Department, Beijing Jiaotong University, Beijing 100044, China \\ 2 Design Department, Politecnico di Milano, 20158 Milan, Italy; han.han@polimi.it \\ 3 Logistics Management and Maritime Studies Department, The Hong Kong Polytechnic University, \\ Hong Kong, China; peter.kc.lee@polyu.edu.hk \\ * Correspondence: yangyefei@bjtu.edu.cn; Tel.: +86-10-5168-7184
}

Academic Editors: Ciwei Dong, Bin Shen, Qingying Li and Patsy Perry

Received: 27 January 2017; Accepted: 20 March 2017; Published: 23 March 2017

\begin{abstract}
In recent years, increasing numbers of luxury groups have adopted sustainable practices in their supply chains (sourcing, manufacturing, logistics, distribution, servicing, waste and recycling). However, the report from Greenpeace International organization (2014) indicates that some luxury brands/companies did not actively conduct sustainable practices to produce items, which is likely attributed to the cost and risks caused by such practices outweighing the benefits. This, to some extent, is due to the failure of developing collaborative practices. Specifically, some luxury brands may fail to develop collaborative practices to create value that are able to benefit multiple stakeholders. Thus, in our study, we explore the value creation mechanism to create sustainable value that benefits not only brands' shareholders, but also other stakeholders, including producers, customers, other stakeholders in the society (e.g., marginalized people) and the environment. In addition, based on a case study from Stella McCartney and Kering and the literature on value creation, we develop a novel model for guiding sustainable value creation (i.e., value co-creation model), where the conceptual building blocks and specific practices are presented. Our contribution lies in extending the knowledge of the value co-creation model from co-creation with customers to co-creation with multiple stakeholders and elaborating systematically and empirically sustainable value co-creation mechanisms including the building blocks and specific practices. In addition, this study offers significant managerial insights for luxury brands/companies to effectively achieve sustainable value.
\end{abstract}

Keywords: sustainability; sustainable value; value co-creation; supply chain; case study

\section{Introduction}

Due to environmental degradation and climate change, the manufacturing industry is forced to adopt more sustainable approaches (e.g., recycled materials, limited packaging and limited used of chemicals) to reduce carbon emission, environmental pollution and energy waste [1,2]. In addition, some literature has proposed that some useful sustainable practices adopted in manufacturing (e.g., the use of organic materials, work welfare enhancement and ethical marketing) can achieve operational efficiency, enhance employee relationship and brand reputation, connect voluntary associations effectively, and improve relationships with responsible investors [3-5]. Some reports relevant to the luxury fashion industry indicate that their practitioners are paying more attention to some the sustainable practices to solve the challenges in terms of how to balance environmental, social and business needs $[1,6]$. 
However, some literature proposes that sustainability is incompatible with the luxury industry [7]. For example, luxury industries generally use unique, valuable and rare materials (e.g., furs and hides) to show social distinction of their products and honor prestige of consumers and focus on the emotional features (i.e., hedonistic) offered by luxury products rather than functional ones, whereas sustainable development places its key concern on the environmental issues (e.g., endangered species and pollution) and ethical issues (e.g., rational and frugal production and consumption) [7-9]. Further, Kapferer indicates that it is difficult to develop sustainable luxury because the alternative fabrics or other materials are less precious than leather or fur that are the dream factors of the luxury concepts [10]. These incompatibilities between luxury fashion and sustainability have resulted in the luxury industry losing motivation to implement sustainable practices. In 2014, the international environmental organization Greenpeace found that almost 2/3 of tested luxurious items (e.g., clothing and footwear) from well-known luxury brands (e.g., Dior, Giorgio Armani, Hermes and Versace) contain at least one toxic material [11]; therefore, it is difficult for luxury brands/companies to actively conduct sustainable practices especially with respect to production. Such evidence indicates that luxury industries do not actively follow sustainable practices to produce items and also indicates that luxury manufacturing's motivation to implement sustainable practices is inadequate. As Alessandro Brun, director of the Master in Global Luxury Management, expressed, "although developments like the continued rise of e-commerce are allowing businesses to cut down on real estate and redesign logistic strategies..., luxury brands are missing great chances to innovate, cut costs and demonstrate their conviction to sustainability to potential customers" [12]. Thus, we need to reconsider the main drivers of implementing sustainable practices in luxury fashion industry and then explore specific practices to enhance such drivers.

Based on De Brito et al. [13] and Caniato et al. [1], the main drivers stimulating the luxury industry to implement sustainable practices can be divided into three categories: (1) Operational-level cost and risk (2) Market-level benefits (3) Law and regulations. In the fashion industry, legislation and regulations are relatively inadequate, and current laws relevant to manufacturing only involve a few elements (e.g., carbon emission constraints and air and water pollution) [1]. The pressure from the law and government is not a very important positive factor that can effectively stimulate luxury companies to implement sustainable practices. Thus, this study places its main consideration on the other two drivers (i.e., operational-level risks and costs and marketing benefits), and based on Porter's study [14], these two issues are the main compositions of value-adding activities. Thus, we need to place our key efforts on exploring how to create the value that benefits multiple stakeholders, including the environment and society, but not without sacrificing shareholders' benefits. Such value is defined by scholars in sustainability and value creation domains as "sustainable value" [15-17]. Consequently, this study further develops the value creation mechanism so as to create sustainable value in the luxury industry.

The literature on value creation can be divided into three classifications: a provided value model, which can be applied to companies clearly specifying customer demands and the marketing environment; the adaptive value model, which can be applied to companies clearly defining customers' demands; and the value co-creation model, which can be applied to companies with complicated environments and ambiguous customer demands [16,17]. In our study, as the extent of sustainable recognition of customer and the competitive environment (e.g., how many peer-fashion companies implement sustainable practices in production process) is unknown; thus, we consider it more appropriate to adopt a value co-creation model to develop a mechanism for sustainable value creation.

Prahalad and Ramaswamy [18] identify four important blocks of interactions between the firms and consumers to co-create value, i.e., dialogue, access, risk-benefits and transparency. These four blocks have certain interactions (e.g., access, and transparency can achieve the assessment of co-value creation, i.e., risks and benefits). To further explain the concepts of the building blocks, access refers to information sharing among partners in marketing; transparency has been an important element of the sustainable supply chain and an important factor influencing consumer's purchasing and consumption 
of sustainable products $[19,20]$ and includes access, dialogue and other soft aspects (e.g., information relevance and reliability) [21]; communication refers to the collaboration with partners (e.g., customers) in marketing literature [22,23]; risks and benefits refer to adequate information and appropriate methods for customers to assess the benefits and risk. Although the studies on value co-creation in marketing have proposed many fruitful insights about how to generate co-creation experience with customers, few studies put their focus on the co-creation of sustainable value that benefits multiple stakeholders from the entire supply chain perspective [24,25]. Thus, this study answers such an urgent call by extending the four building blocks to entire supply chain discussions and exploring more specific practices of every block.

This study mainly explores how to develop a sustainable value mechanism in the luxury industry. Firstly, based on the literature on the value creation model and sustainability, this study analyzes three main value creation models, their applicable conditions and the characteristics of sustainable value and the luxury market, and then proposes the most appropriate model (i.e., value co-creation model) to develop a sustainable value creation mechanism. Considering the four building blocks of the co-creation model (i.e., access, dialogue, communication and benefit and risks), this study adapts it to four building blocks of sustainable value co-creation (i.e., access, cooperation, supply chain transparency and risks and benefits of environmental impacts). Based on the elaboration of the cases (McCartney and Kering), this study further explores specific practices for each building block (e.g., diffuse sustainable value associated with the collaboration relationships with other brands and expanded strategic partnership with NGOs). It hence systematically develops the mechanism for sustainable value creation including building blocks and respective practices from the supply chain perspective that not only enriches value creation literature and sustainability literature, but also offers specific guidelines for operation managers and top management in the luxury industry.

\section{Literature Review and Framework Development}

\subsection{Sustainability in the Luxury Fashion Industry}

Scholars have proposed various firm measures and programs relevant to green manufacturing and the green supply chain, which can be identified as three critical categories, i.e., new operational technologies (e.g., implementation of end-of-pipe technologies), green product development (e.g., eco-efficient product development and life-cycle assessment methodology development) and green practices integrated in the supply chain (e.g., supply chain design involving the application of environmentally friendly solutions) [26-30]. It is true that in the fashion industry, more and more companies (e.g., Veja and Patagonia) have started to adopt different sustainable strategies and practices (e.g., use of eco-friendly materials, reuse and recycling of materials, clean production, green certifications and green products) so as to pursue green manufacturing and supply chains [13,31-33]. Many studies have indicated that the "green fashion" can enhance their brand image, improve fashion companies' competiveness and retain more customers [34-36]. Luxury product manufacturers consider not only the quality and uniqueness of their products, but also the ethical factors to meet their consumers' expectations with environmental protection $[7,37]$.

However, a report from the Greenpeace Organization [11] indicates that the luxury industries still lack sufficient motivation to achieve sustainability. De Brito et al. [13] and Caniato et al. [1] identify the drivers of sustainability implementation in three categories, i.e., (1) Operational-level cost and risk (2) Market-level benefits (3) Law and regulations. Schrettle et al. [38] classify the drivers into two aspects (i.e., external and internal factor): external factors involve environmental regulation, ethical norms and market drivers; the internal factors involve resources and strategy. In addition, a study [1] indicated that legislation and regulations are relatively inadequate in the fashion industry, and current laws and regulations for textile manufacturing only involve general practices (e.g., reducing carbon and pollution emission) and the pressure from norms and regulations is not a significant factor pushing the implementation of sustainable practices. Thus, it is essential to consider market factors 
(i.e., market-level benefits) and internal resources (operational-level cost and risk) as main drivers. Indeed, luxury manufacturers lacking adequate motivation could be attributed to the benefits of implementing sustainable practices that are much less than the costs. For example, some companies invest high amounts to transfer conventional production into green production (e.g., the use of organic cotton that is produced without hazardous chemicals such as pesticides and fertilizers), while the market share only accounts for $0.1 \%$ of the total clothing market worldwide due to customers' demand and preference [39]. Consequently, considering that the main drivers (i.e., market benefits and costs) are the important elements of value creation [14], this study explores how to create sustainable value for the environment, manufacturers, as well as other stakeholders.

\subsection{Sustainable Value and Value Co-Creation Models}

Most studies on sustainable value mainly focus on its definition and how to achieve such value by aligning sustainability with business strategies. For example, Hart and Milstein [15] propose the framework of sustainable value that connects the four drivers of sustainability (i.e., clean technology, sustainability vision, pollution prevention and product recycling) with business strategies and practices corresponding to shareholder benefits (i.e., innovation, growth trajectory, costs and risk reduction, and reputation and legitimacy). Ueda et al. [16], according to the definitions of sustainability in different contexts and types of value, integrate environmental value, pragmatic value, economic value and psychological value as sustainable value. Badurdeen et al. [17] define sustainable value as the value that can be generated for shareholders and other stakeholders, which can be evaluated by economic, environmental and societal benefits. Further, Christopher et al. [40] indicate that the services that supply chain delivery to the customers can create more and more value, which is also elaborated in the field of service-dominant logic discussions and shows the important role of supply chains in value creation [41,42]. Thus, in our study, we conceptualize sustainable value in the luxury industry from the supply chain perspective as the value that is created only when business activities are beneficial for each party of supply chain partners, the environment and society. The issues indicate that how to create sustainable value in the luxury industry is the key to be further studied systematically.

Current studies on value creation models mainly focus on three types-providing value model, adaptive value model, and value co-creation model [16,43,44].

Specifically, the providing value model involves producers, products/service and customers, and their values are separable. Producers can obtain complete information from customers and deliver the complete specification to the production system. The environment (e.g., resource and workforce) can be described completely. Such a closed system creates value in products or service (i.e., only when products/services have been traded in the market can the value be generated) and is mainly suitable for mass-produced products or routine service. The providing value creation model can achieve minimum costs, and the main practices are issues relevant to optimization (as Figure 1a).

The adaptive value creation model involves producers, consumers and products/services. The customers' objectives can be obtained, but the environment is uncertain (e.g., social influence and environment resource). The value creation model is an open system for the environment, and producers adopt adaptive strategies responding to environmental changes. The model is suitable for consumer-oriented goods. The value is created in the process of products/service trade (i.e., only when products/services have been traded in the market can the value be generated) and the value is also related to the environment because the manufacturing process is efficiency-oriented and aims to reduce resource waste and pollution emission. The practices of the adaptive value creation model are practices relevant to learning and knowledge management (e.g., explorative learning and tacit knowledge achievement) to enhance producers' adaptive behaviors [45,46] (as Figure 1b).

The co-creative value model involves producers, customers, and products/service, and creates value by interaction activities engaging producers, customers and environment in uncertain environmental information and ambiguous objectives. Such a model is open to both the customers and environment, achieving a win-win game (as Figure 1c). Value creation process involves consumers' 
participation in the service and product creation and considers the environmental interactions, thereby generating innovation value in the whole process that is not separable for consumers, producers and environment. Based on the value creation models, our study considers the applicable conditions of each value creation model as well as the characteristics of sustainable value in the luxury industry to choose the valid value creation model and respective practices achieving value creation in a certain context. The practices of the co-creation value model are exhibited in terms of dialogue, access, risk-benefits, and transparency, and the practices relevant to dialog, access, and transparency can achieve the assessment of co-value creation, i.e., risks and benefits [18]. Transparency has been realized as a crucial element of sustainable supply chains and an essential factor influencing consumer's purchase decision and consumption practice toward sustainable products $[19,20]$. Moreover, transparency is a concept that integrates the other concepts including access, dialogue and other soft aspects (e.g., information relevance and reliability) [21]. This study, with regard to the characteristics of luxury manufacturing and the main problems of sustainability in luxury industry, further analyzes which value creation model can be applicable for the sustainable value creation of luxury segments and then designs specific building blocks and the respective practices assisting in achieving the effectiveness of this model.

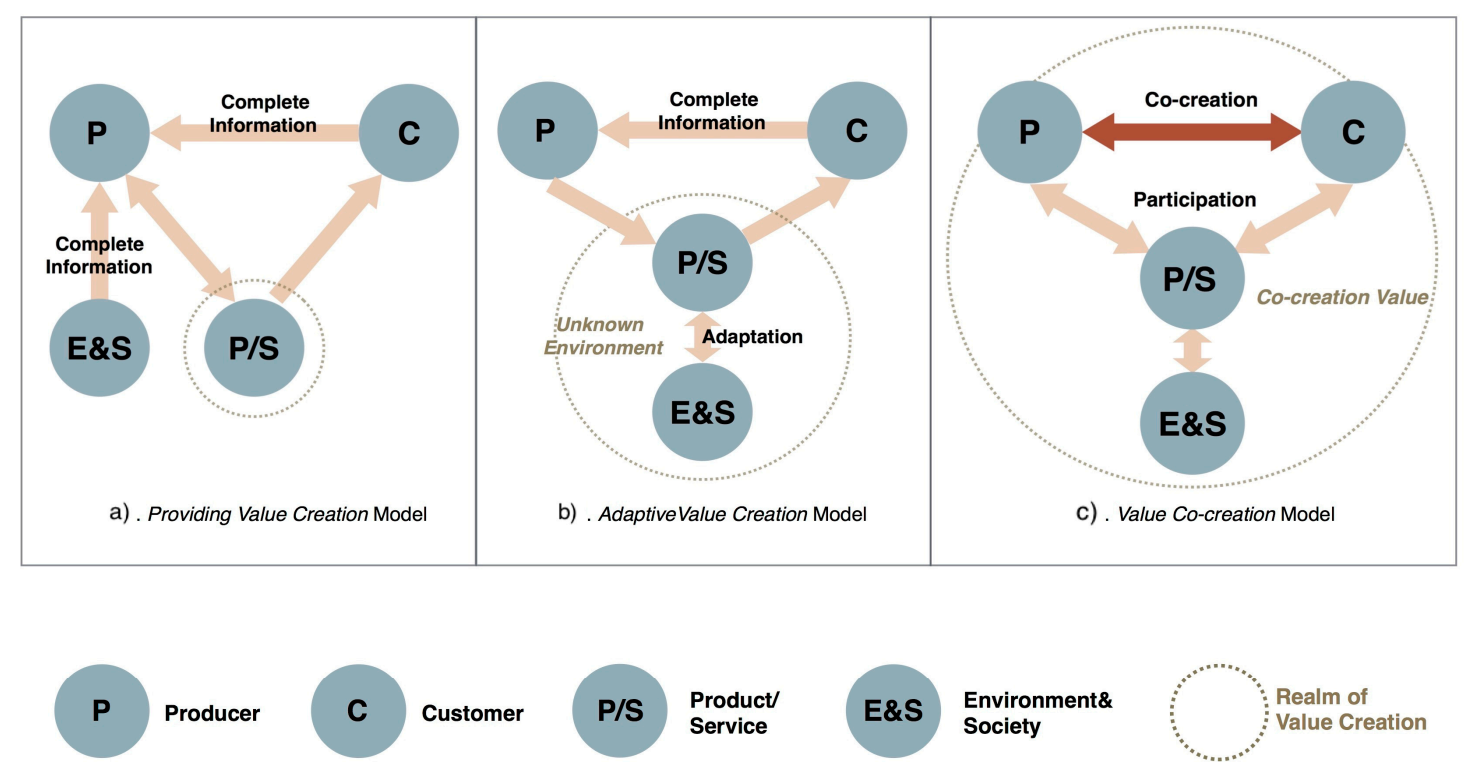

Figure 1. Three types of Value Creation Models. (a) Providing Value Creation; (b) Adaptive Value Creation Model; (c) Value Co-creation Model.

\section{Sustainable Value Creation Mechanism Development}

\subsection{The Operational Characteristics of Luxury Manufacturing}

The empirical studies on competitive operational factors in luxury segments mainly show efforts associated with issues of premium quality, operation technologies (i.e., craftsmanship), uniqueness, volume variability and product complexity [47-50]. To be more specific, firstly, uniqueness and premium quality are common characteristics of operational processes in luxury manufacturing, which obviously distinguish luxury products from mass-produced ones [1] and indicate that providing the value creation model is not applicable for value creation in luxury manufacturing. Secondly, two other characteristics of luxury are product variety and selling volume variety, as luxury manufacturing offers variations in its products in order to assure uniqueness, which may imply low selling volume for certain product categories $[49,51]$. These characteristics manifest the dynamic need of luxury consumers, which makes luxury brands not applicable to the model of customer-oriented value creation (i.e., adaptive value creation model). Therefore, in consideration of the operational characteristics of 
the luxury industry discussed above (i.e., uniqueness, premium quality, product variety and selling volume variety), the co-creation model is the most applicable for the luxury industry.

\subsection{Sustainable Value Co-Creation Model}

The literature on sustainability in the luxury industry indicates that consumers' preference and demand for sustainability are highly varied and uncertain [40]. For example, the study of Devinney et al. [52] indicates that consumers are willing to pay higher prices for organic and green products, whereas the discussion of Auger et al. [53] stresses that some consumers are not willing to pay for the expense of ethical attributes. In addition the raw materials used for luxury products are sourced from different countries (e.g., leather in Italy, cashmere wool in India and other cloth in China), and the production phases are outsourced or implemented in different locations (e.g., their critical production phases are performed in house, and non-critical phases are outsourced to labor-intensive districts) [54]. Although the focal companies wish to produce products with ethical consideration, it is difficult to keep the entire supply chain (e.g., materials procurement and production process) under proper control. In addition, the benefits of implementing sustainable practices are much less than the costs [40]. Thus, the main challenges in creating sustainable value in the luxury industry are the incomplete information from the market (e.g., customer preference), difficultly controlling entire material flow and partnership, and benefit and loss relevant to the environmental impact of the supply chain. Regarding this point, Perrini and Tencati [55] suggested that sustainable value creation is based on constructive stakeholder relationships in the supply chain. Facing these main challenges, this study explores the mechanism for sustainable value co-creation from four dimensions-information flow, main partners, material flow, and benefit and cost relevant to environments.

According to the value co-creation model ([16,44] as Figure 1c), this study extends the partners (i.e., producers, customers and environment) to multiple stakeholders (i.e., suppliers, producers, distributors, consumers, focal companies, society and environment). The party of product/service has been extended to the material flow from raw materials to finished products. The co-creation process has been extended from co-creation with consumers to co-creation with multi-stakeholders. The focal brands/companies co-create value with the suppliers, producers, distributors, customers, environment and society. To be more specific, suppliers promptly update the information of sustainable raw materials and R\&D about alternative materials to the focal brands/companies; consumers need to be engaged in product design as they offer purchase preferences and demand of the merchandise and at the same time, should be encouraged to focus on environmental interactions (e.g., reducing the use of packaging and refusing the use of fur); producers obtain comprehensive information about the raw materials and customers' preference to conduct production activities with consideration of resource reduction (e.g., efficiency-oriented production) and environmental protection; finally, retailers deliver products to the end-consumers in environmental and economic manners. Such co-creation experiences and processes with comprehensive information and product specifications are able to solve the problems of incomplete information from the market (e.g., customer preference), make the material transparent, enhance the cooperation among partnerships, and easily calculate the benefit and loss relevant to the environmental impact of the entire supply chain (as Figure 2). 


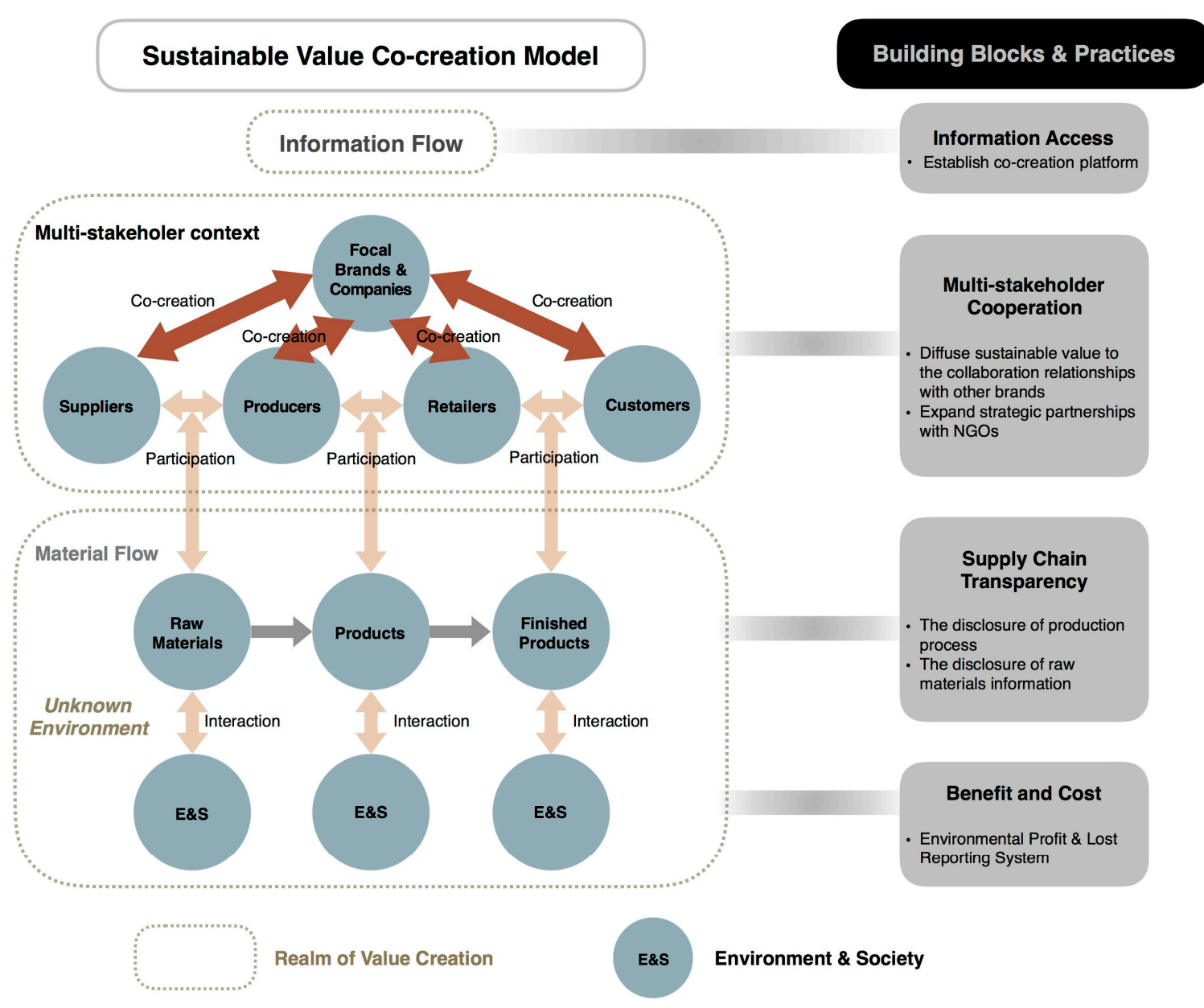

Figure 2. Sustainable Value Co-creation Mechanism.

\section{The Cases to Elaborate the Sustainable Value Co-Creation Mechanism}

\subsection{The Case Study Approach}

An exploratory case study approach is chosen here as the main method to explore new frameworks and mechanisms relevant to under-studied research topics [56]. The approach of case studies can provide more available evidence to develop hypotheses and has been identified as one of the most commonly used methodologies in supply chain studies in response to the complicated situations $[57,58]$. Our study develops a sustainable value co-creation mechanism, involving multiple stakeholders and the entire supply chain. It is difficult to directly obtain first-hand data using a survey. Thus, this study adopts an exploratory technique to develop specific practices to elaborate the relevant building blocks of the sustainable value co-creation mechanism.

\subsection{The Case Study Firms}

This study selects Stella McCartney located in England and its parent company Kering located in Pairs of France as our cases. Rationales for the case selections are: Firstly, Stella McCartney is the role model as a sustainable luxury fashion brand that has developed a successful operational business model to produce ethical and sustainable products and achieve increasing profitability. For instance, the sales of Stella McCartney have continuously increased from \$18.2 million in 2005 to \$44.3 million in 2013, and profits for the UK branch reached \$5.6 million in 2013 [59,60]. Secondly, environment awareness and moral convictions are Stella McCartney's original aspects of her belief and value system, which is different from the designers or brand managers who implement sustainable practices for the 
purpose of answering the external requests and social pressures [61]. Further, Stella McCartney makes an effort to educate and convince other brands to take sustainable production into account in their practices (e.g., seeking alternatives for precious animal-based materials) [60]. Such a belief and value system urged Stella to continuously implement various kinds of valuable programs to achieve more sustainable value. Thirdly, Stella McCartney communicates and cooperates with her main supply chain partners and develops programs to evaluate the benefit and risks [62], which involve the main building blocks of value co-creation based on a multi-stakeholder context. Finally, Stella McCartney is one of the luxury brands in Kering's conglomerate. As Kering's top management groups also perceive sustainability as an opportunity to create value and stimulate innovation, its leadership support and series of sustainability strategies to some extent assist Stella McCartney's success in implementing sustainable practices. Thus, the cases of Stella McCartney and Kering are taken as best practices to analyze and elaborate the value-creation mechanism.

\subsection{Data Collection}

Because of the unclear definition of the boundaries between contemporary phenomenon and real-life context, this study employs the case study approach to elaborate the mechanism for sustainable value co-creation in the luxury industry [56]. Firstly, in order to select proper cases to study, we collected abundant news releases and reports about sustainability in luxury industries (e.g., the luxury brand Burberry in 2015 invested $£ 50$ million for incorporating green practices in their manufacturing; Gucci make a great effort to achieve sustainable production) from the database of Factiva to find out the appropriate luxury brand that better reflects the sustainable value creation after qualitative content analysis of the articles as pre-comprehension studies [63]. From the comparisons and analysis, it is found that many luxury groups have indeed adopted sustainable practices into the various phases of the supply chain, irrespective of sourcing, manufacturing, logistics, distribution, servicing, or waste and recycling. However, these brands adopt eco-production or eco-marketing (i.e., parts of their operations) but neglect to cover the supply chain as a whole. As a result of such pre-comprehension studies, Stella McCartney is distinct from those brands with eco-lines or eco-collections, because Stella McCartney perceives sustainability as its core ethos and the brand DNA, and it is a leading brand with the launch of ethical initiatives from raw materials to finished products and retail spaces. Therefore, Stella McCartney and its parent company Kering are selected as the study cases. We then collected and analyzed the accessible field data for the chosen cases over a three-month period using qualitative methods-direct observations and document analysis dealing with various types of data resources including the brands' official websites, posts on the social-network websites (both official and other bloggers), news releases from other platforms, secondary data from interview reports with the chief officers and the top management group regarding the sustainability issues from both Stella McCartney and the Kering Group. In addition, using inductive analysis, this study also proposes the propositions according to the different practices of each building block involved in the value co-creation mechanism.

\subsection{Findings and Discussion}

This study discusses and presents the main practices to provide comprehensive information flow and product specifications (i.e., the building block information access), achieve co-operation with multiple stakeholders (i.e., the building block multi-stakeholder cooperation), assure green consideration from raw materials to finished products (i.e., the building block supply chain transparency), and measure the benefits and risks involving the loss and profits of environmental impacts (i.e., the building block benefits and risks) (as Figure 2).

\subsubsection{Information Access-Establishing the Co-Creation Platform}

The first building block of the sustainable value co-creation model is to provide complete information flow and product specification, which is consistent with the relevant literature on the 
block of information access in the value co-creation model [18]. From the case, this study finds the main practice of this block is establishing the co-creation platform. Specifically, luxury brands should establish websites (e.g., Clevercare initiative) to help customers to extend the life cycle of their clothing with more environmental practices and co-creation with customers' prior ordering. Further, websites like Clevercare initiative provide a platform as the open source for customers and other partners to express their demand and green considerations and to share their information. It not only reduces the waste and controls the product inventory, achieving sustainable operations, but also considers dynamic market demand to complete the environmental production and delivery. The news announcements and interviews with Stella McCartney are specified as follows (Ivey case base):

"In 2014, we helped launch the Clevercare initiative. The Clevercare initiative links customers to the clevercare. info website which provides tips on how to extend the life of their clothing through using more environmentally friendly cleaning practices. From Spring 2015, all of our collections will feature the Clevercare logo-a simple reminder to consider the environment when washing and caring for your garments."

"In 2015, Stella McCartney collaborated with Adidas and outlined a commitment to what it calls 'open source'. This is essentially co-creation with customers, athletes and other partners."

Proposition 1. Establishing a co-creation platform can create value for multi-stakeholders through information access.

\subsubsection{Multi-Stakeholder Cooperation}

The second building block of the sustainable value co-creation model is to achieve co-operation with multiple stakeholders, which is consistent with the relevant literature on block of communication in the value co-creation model [18]. From the case, this study finds the two main practices of this block are (1) diffusing sustainable value to the collaboration relationships with other brands; (2) expanding Strategic Partnerships with NGOs. Specific details of the two practices follow.

(1) Diffusing sustainable value to the collaboration relationships with other brands

Stella McCartney brings the same set of beliefs and value system carried by her fashion house to her strategic collaborators such as Adidas and H\&M to reinforce her sustainability practices. For example, the objective of Stella McCartney collaborating with Adidas is to bring ethical practices and fashion elements into performance wear and the standards of the choosing cooperator are to have a good reputation and a good value system [64]. Stella McCartney as a focal company took a leading role in diffusing ethical practices and fashion elements to other collaborators, and co-innovated sustainable products are warmly welcomed by customers. By such cooperation with the fast fashion industry (e.g., H\&M), the ethical products of Stella McCartney are known and accessed by more customers, thereby enlarging their potential target customers. Such cooperation practice can also offer the platform facilitating Stella McCartney to delivery the value of ethical products with customer more easily, thereby achieving more information of customer needs. Thus, collaboration with other brands can help luxurious brands diffuse their ethical products into larger markets, thereby creating sustainable value. The statements from Stella McCartney are as follows:

“The only reason I'm doing this is because I personally feel that for women what's out there at the moment is kind of insulting; it's really not good enough on all levels. To be honest I knew Michael Michalsky [Adidas's global creative director] anyway. But I always felt they had integrity, and you have to be careful who you partner with, who you lie in bed with, when you work in my industry. I felt Adidas has a good reputation, are a solid company and have a good value system ..."

"We did that collaboration a long time ago before it became the thing to do. We were one of the first to do it. It was great. It was a one-off explosion of craziness. We sold out in $30 \mathrm{~min}$ or something. I remember the footage of women grabbing everything. It was exciting" [65]. 
(2) Expanding strategic partnerships with NGOs

Stella McCartney developed close relationship with many non-governmental organizations (NGOs) such as the Natural Resource Defense Council's (NRDC), Ethical Trading Initiative (ETI) and Ethical Fashion Initiative to seek local labour such as marginalized people and to build relationship with local producers. These collaboration projects improve working conditions and employees' income in poverty districts (e.g., Kenya) and encourage small communities to reproduce similar initiatives, which connect the impoverished and backward counties to the luxury fashion industry. Further, products are produced in the resource base, which can reduce waste associated with warehouses and transportation. Thus, expanding strategic partnerships with NGOs can achieve mutual benefits between local producers and the entrepreneurs. The news release from K Magazine of Kering 2014 about "Fashion's New Continent" and "Stella McCartney Bags Made in Kenya" is as follows:

"What we are seeing emerging is that you can get cotton that is grown in Arusha, an area in Tanzania, turned into fabric in Arusha, then dyed and stitched and shipped out of Arusha as a local garment" commented Conall O'Caoimh, director of Value Added in Africa, a charity that built relationships between local producers and European retailers.

“We continue our partnership with the United Nations' International Trade Centre Ethical Fashion Initiative. The Initiative connects some of the world's most marginalized people with the top of fashion's value chain, for mutual benefit."

“In 2012 we joined the Ethical Trading Initiative (ETI), an alliance of companies, voluntary organizations and trade unions, all working together to improve working conditions around the world. These collaborative projects were setting a trend and inspiring local producers and entrepreneurs to reproduce similar initiatives, gain training from E.T.I., get a job and grow their skills. "To have the work in Kenya is important," declared McCartney, "not only to support women and give them a much-needed income, but also to encourage this line of industry for small communities... [It's] a two-way street—everyone feels valid."

Proposition 2. Multi-stakeholder cooperation, i.e., (a) diffusing sustainable value to the collaboration relationships with other brands; and (b) expanding strategic partnerships with NGOs can both create sustainable value.

\subsubsection{Supply Chain Transparency}

The third building block of the sustainable value co-creation model is to assure green consideration from raw materials to finished products, which is consistent with the relevant literature on the block of supply chain transparency in the value co-creation model [18]. From the case, this study finds the two main practices of this block are (1) the disclosure of production process; (2) the disclosure of raw material information. Specific details of the two practices follow.

(1) The disclosure of the production process

Stella McCartney and Kering are developing an innovative form to measure the costs and benefits of the environmental impact, that is, the environmental profit and loss (E P\&L) reporting system. The E P\&L reporting system considers all activities throughout the supply chain to calculate the environmental footprints from the production of raw materials to finished products (i.e., from cradle to cradle) and trace these activities involving environmental problems such as carbon emissions, water consumption, land use, air and water pollution and resource waste, which provides supply chain visibility and tractability. It can help stakeholders learn more about the brands and guide companies to assign monetary values to solve the environmental challenges they face. A specific news release from the Kering official website follows: 
“Environmental Profit and Loss (E P\&L) allows a company to measure in monetary value measure the costs and benefits it generates for the environment and in turn make more sustainable business decisions. It facilitates a new way of thinking by providing us with a high level of visibility taking into account carbon emissions, water use and pollution, land use, air pollution and waste levels... It values the environmental impacts of business across the entire supply chain... Conducting an E P\&L will unlock new insights into the supply chain and help you discover the efficiency, innovations and improvements... it opened a dialogue with stakeholders allowing us to share learning and develop understanding on priorities and helps our suppliers identify opportunities for improvement and innovation."

(2) The disclosure of raw materials information

Stella McCartney makes the commitment that she uses all of her raw materials such as viscose and cellulose fabric certified as sustainable materials in 2017. They never give up the continuous search for more natural materials and the use of organic cotton and fabrics. Further, as the information of raw materials (e.g., organic cotton) is increasingly being disclosed, the customers' acceptance rate of green products also increases continuously, thereby increasing the sales of organic products. Respective evidence from the data of McCartney can be seen as follows (Ivey case base):

"Organic cotton farming uses water efficiently, does not involve harmful chemicals, restores and maintains soil health and promotes high social and working standards for farmers" In 2014, we increased our use of certified organic cotton; $72 \%$ of our denim collection was made from organic cotton and $54 \%$ of our cotton jersey was made from organic cotton. Additionally, in 2014, 74\% of the cotton used in our kidswear collection was organic cotton."

"In 2014, we began our partnership with the NGO Canopy, and we made a commitment to ensure that all of our viscose and other cellulose fabrics (fabrics that come from wood pulp) are sustainably certified by 2017. In 2014, we increased our use of certified organic cotton; $72 \%$ of our denim collection was made from organic cotton and $54 \%$ of our cotton jersey was made from organic cotton. An increase from 2013. In 2013, 51\% of our denim and 25\% of our jersey for ready-to-wear was made from organic cotton. Additionally, in 2014, 74\% of the cotton used in our kidswear collection was organic cotton. Organic cotton farming uses water efficiently, does not involve harmful chemicals, restores and maintains soil health and promotes high social and working standards for farmers."

In addition, Stella developed some high-quality alternative materials such as fur-free-fur pieces and disclosed instructions by attaching these in visible places. Moreover, Kering also initiated "freedom within the framework" actions, which means each design group is free to decide how to adopt sustainable practices (e.g., choosing diamonds from certified sources and producing clothing by using recycled material or completely PVC-free material) to create more fashion elements. The activities of disclosing their raw materials help customers understand this ethos of the brands and inspire designers to creatively and flexibly develop more sustainable raw materials and designs, thereby benefiting shareholders and environment. Respective evidence from the data of McCartney can be seen as follows (Ivey case base):

"Modern fake fur looks so much like real fur, that the moment it leaves the atelier no one can tell it's not the real thing and I've struggled with that. But I've been speaking to younger women about it recently and they don't even want real fur. So I feel like maybe things have moved on, and it's time, and we can do fabrics which look like fur, if we take them somewhere else."

Proposition 3. Supply chain transparency, i.e., (a) the disclosure of the production process and (b) the disclosure of raw materials can create sustainable value. 
4.4.4. Benefit and Cost Associated with Environmental Impact-Environmental Profit and Loss (E P\&L) Reporting System

The final building block of the sustainable value co-creation model is to involve the loss and profits of environmental impact, which is consistent with the relevant literature on the block of benefits and risk block of information access in the value co-creation model [18]. From the case, this study finds that the main practice of this block is to introduce the Environmental Profit and Loss (E P\&L) reporting system. Specifically, Kering and McCartney perform powerful work to monetize the costs and benefits of environmental impacts. This can provide clear information on operational processes from raw materials to finished products and analyze the existing problems of the supply chains and guide investments in improving the efficiency of production or delivery phases or any connection with unexpected waste, thereby reducing operational costs, environmental waste and pollution. The statements from the Kering official website explicitly disclose the evidence suggesting this point:

“The Environmental Profit and Loss (E P\&L) reporting system offers a greater understanding of risks and opportunities, because it helps to discover some potential efficiency and challenges. Understanding risks and opportunities means that our business is fully prepared to respond to challenges. We have produced guidelines, polices and measurable targets to make progress across a wide range of raw materials."

Proposition 4. Environmental Profit and Loss (E PEL) reporting system can create sustainable value.

\section{Conclusions and Discussion}

This study mainly explores how to create sustainable value in the luxury industry. Although the literature on sustainability has proposed that many sustainable practices (e.g., recycled materials, limited packaging and limited used of chemicals) [1,2] are capable of helping companies design, produce products, control inventory and deliver their products, these practices are not being widely implemented by luxury brands. Brun [12], the director of the Master in Global Luxury Management at MIP Politecnico di Milano, indicates that many companies are not willing to adopt certain sustainable practices to ensure sustainability or fail to develop collaborative approaches in the supply chain to create some value (e.g., cutting costs and attracting more potential customers) through sustainability. Thus, in our study, we explore the value creation mechanism to create sustainable value that benefits not only shareholders, but also multiple stakeholders, including producers, customers, other social parties in the communities (e.g., marginalized people), and environments. Firstly, we analyze three main value creation models, their applicable conditions the characteristics of sustainable value as well as the luxury market, and then propose the most appropriate model (i.e., value co-creation model) and four building blocks (i.e., information access, multi-stakeholder cooperation, supply chain transparency, and risks and benefits of environmental impact). Based on the elaboration of the cases (McCartney and Kering), this study explores possible practices in each block (e.g., diffuse sustainable value into the collaboration relationships with other brands and expand strategic partnerships with NGOs). With the exploratory case study approach, this study systematically develops the sustainable value co-creation mechanism for multiple stakeholders including the building blocks and respective practices. It not only enriches value creation literature and sustainability literature, but also offers specific guidelines for branding practitioners and top management executives in the luxury fashion industry.

\subsection{Theoretical Implications}

The first theoretical contribution of this study is to apply marketing knowledge on value creation models to create sustainable value for multiple stakeholders from the supply chain perspective, as the concept of the value co-creation model is extended from the company-to-customer dimension in marketing studies $[22,23]$ to a larger company-with-partners dimension throughout its supply chain. Our study enriches and extends the literature on the value creation models and the literature on sustainable value. 
The second theoretical contribution of this study is to elaborate, systematically and empirically, the mechanism for sustainable value co-creation including the building blocks and respective practices. Considering prior literature regarding the four building blocks and their conceptualizations, this study adapts the main building blocks as information access, multi-stakeholder cooperation, supply chain transparency, and benefits and risks of environmental impact, as well as the exploration of the respective practices by a case study approach. Our study supplements and enriches the studies on value co-creation.

\subsection{Managerial Implications}

Managerial implications mainly provide guidelines on how to create sustainable value for luxury brands/companies that benefits both shareholders and other multiple stakeholders. Our study provides possible practices: for the building block access, focal companies need to establish a co-creation platform to encourage customers and partnerships to exchange information, thereby continuously improve business operations and reduce resource waste and pollution; for the building block multi-stakeholder cooperation, focal companies need to diffuse sustainable belief and value systems in their collaboration relationships with other brands and expand strategic partnership with NGOs, which can assure sustainability implementation from raw materials to finished products and seek suitable local producers nearby the materials base. This will improve the income level of poverty districts and reduce operational costs as mutual benefits. For the building block supply chain transparency, focal companies need to disclose the operational processes by calculating their products' footprints and disclose information of the raw materials, which enhances consumers' understanding of the brand's ethos and attracts more potential customers, thereby creating more value. For the building block benefit and risk, focal companies need to acquire a reporting system similar to the Environment Profit and Loss system to monitor environmental impacts, which efficiently facilitates the enterprises to identify existing problems and improve their operational processes.

\subsection{Limitation and Future Study}

The limitations of this study show the potential for future research. Firstly, this study adopts the exploratory case study approach with qualitative methods to explore our framework and propose some specific practices, which did not result in a strong conclusion, e.g., the value that is increased by these strategies. Further explorations will make a significant contribution in determining whether these practices are sufficient in value creation using quantitative approaches (e.g., obtaining further secondary data to build economic models or obtaining primary data and conducting quantitative data analysis). Secondly, as this study adopts the cases of Stella McCartney and Kering, it may be difficult to be directly applied to the fast fashion industry. Future studies can therefore develop the mechanism for sustainable value co-creation adapted from this one in response the characteristics of the fast fashion industry. Finally, this study mainly considered the important practices of the co-creation mechanism, but we need further consider of more detailed practices from every important aspect of the co-creation mechanism.

Acknowledgments: I have received support from the project of Beijing Jiaotong University (code B16RC00040), which offers funds for covering the costs to publish in open access journals. In addition, the cost of data collection was partially supported by the National Natural Science Foundation of China (grant No. 71661167009).

Author Contributions: For research articles with three authors, the contributions are specified: Yefei Yang, Han Han and Peter K.C. Lee developed the conceptual model; Yefei Yang wrote the paper; Han Han collected the case materials and did the proofreading; Peter K.C. Lee further revised the paper.

Conflicts of Interest: The authors declare no conflict of interest.

\section{References}

1. Caniato, F.; Caridi, M.; Crippa, L.; Moretto, A. Environmental sustainability in fashion supply chains: An exploratory case based research. Int. J. Prod. Econ. 2012, 135, 659-670. [CrossRef] 
2. Fiksel, J. Meeting the Challenge of Sustainable Supply Chain Management. In Treatise on Sustainability Science and Engineering; Springer: Dordrecht, The Netherlands, 2013; pp. 269-289.

3. Bendell, J.; Kleanthous, A. Deeper Luxury: Quality and Style when the World Matters. World Wildlife Federation-UK. Available online: www.wwf.org.uk/deeperluxury (accessed on 23 April 2013).

4. Dangelico, R.M.; Pujari, D. Mainstreaming green product innovation: Why and how companies integrate environmental sustainability. J. Bus. Ethics 2010, 95, 471-486. [CrossRef]

5. Gunasekaran, A.; Spalanzani, A. Sustainability of manufacturing and services: Investigations for research and applications. Int. J. Prod. Econ. 2012, 140, 35-47. [CrossRef]

6. Joy, A.; Sherry, J.F., Jr.; Venkatesh, A.; Wang, J.; Chan, R. Fast fashion, sustainability, and the ethical appeal of luxury brands. Fash. Theory 2012, 16, 273-295. [CrossRef]

7. Lochard, C.; Murat, A. Luxe et Développement Durable: La Nouvelle Alliance; Eyrolles: Paris, France, 2011.

8. Vigneron, F.; Johnson, L. Measuring Perceptions of Brand Luxury. J. Brand Manag. 2004, 11, 484-506. [CrossRef]

9. Pascaud, L. Could Sustainability Be the Future of Luxury? Available online: http:/ /staging.luxurysociety. com/en/articles/contributors/leslie-pascaud (accessed on 24 November 2011).

10. Kapferer, J.N. Abundant rarity: The key to luxury growth. Bus. Horiz. 2012, 55, 453-462. [CrossRef]

11. Greenpeace International. A Little Story about a Fashionable Lie. Available online: http:/ /www.greenpeace.org/ international/en/publications/Campaign-reports/Toxics-reports/A-Little-Story-about-a-Fashionable-Lie/ (accessed on 17 February 2014).

12. Brun, A. M2 Presswire. Available online: http://www.m2.com (accessed on 10 December 2016).

13. De Brito, M.P.; Carbone, V.; Blanquart, C.M. Towards a sustainable fashion retail supply chain in Europe: Organisation and performance. Int. J. Prod. Econ. 2008, 114, 534-553. [CrossRef]

14. Porter, M.E. Competitive Advantage; Free Press: New York, NY, USA, 1985.

15. Hart, S.L.; Milstein, M.B. Creating sustainable value. Acad. Manag. Executive 2003, 17, 56-67. [CrossRef]

16. Ueda, K.; Takenaka, T.; Vancza, J.; Monostori, L. Value creation anddecision-making in sustainable society. CIRP Ann. Manuf. 2009, 58, 681-700.

17. Badurdeen, F.; Goldsby, T.J.; Iyengar, D.; Jawahir, I.S. Transforming supply chains to create sustainable value for all stakeholders. In Treatise on Sustainability Science and Engineering; Springer: Dordrech, The Netherlands, 2013; pp. 311-338.

18. Prahalad, C.K.; Ramaswamy, V. Co-creation experiences: The next practice in value creation. J. Interact. Market. 2004, 18, 5-14.

19. Carter, C.R.; Rogers, D.S. A framework of sustainable supply chain management: Moving toward new theory. Int. J. Phys. Distrib. Logist. Manag. 2008, 38, 360-387. [CrossRef]

20. Bhaduri, G.; Ha-Brookshire, J.E. Do transparent business practices pay? Exploration of transparency and consumer purchase intention. Cloth. Text. Res. J. 2011, 29, 135-149. [CrossRef]

21. Vishwanath, T.; Kaufmann, D. Toward transparency: New approaches and their application to financial markets. World Bank Res. Obs. 2001, 16, 41-57. [CrossRef]

22. Anker, T.B.; Sparks, L.; Moutinho, L.; Grönroos, C. Consumer dominant value creation: A theoretical response to the recent call for a consumer dominant logic for marketing. Eur. J. Market. 2015, 49, 532-560.

23. Grönroos, C. Value co-creation in service-logic: A critical analysis. Market. Theory 2011, 11, 279-301. [CrossRef]

24. Kornum, N.; Mühlbacher, H. Multi-stakeholder virtual dialogue: Introduction to the special issue. J. Bus. Res. 2013, 66, 1460-1464. [CrossRef]

25. Vallaster, C.; von Wallpach, S. An online discursive inquiry into the social dynamics of multi-stakeholder brand meaning co-creation. J. Bus. Res. 2013, 66, 1505-1515. [CrossRef]

26. Kleindorfer, P.R.; Singhal, K.; Wassenhove, L.N. Sustainable operations management. Prod. Oper. Manag. 2005, 14, 482-492. [CrossRef]

27. Vachon, S.; Klassen, R.D. Environmental management and manufacturing performance: The role of collaboration in the supply chain. Int. J. Prod. Econ. 2008, 111, 299-315. [CrossRef]

28. Sinha, R.V.; Noble, S.H. The adoption of radical manufacturing technologies and firm survival. Strateg. Manag. J. 2008, 29, 943-962. [CrossRef]

29. Kengpol, A.; Boonkanit, P. The decision support framework for developing eco-design at conceptual phase based upon ISO/TR14062. Int. J. Prod. Econ. 2011, 131, 4-14. [CrossRef] 
30. Ubeda, S.; Arcelus, F.J.; Faulin, J. Green logistics at Eroski: A case study. Int. J. Prod. Econ. 2011, 131, 44-51. [CrossRef]

31. Chouinard, Y.; Brown, M.S. Going organic: Converting Patagonia's cotton product line. J. Ind. Ecol. 1997, 1, 117-129. [CrossRef]

32. Nieminen, E.; Linke, M.; Tobler, M.; Vander Becke, B. EU COST Action 628: Life cycle assessment (LCA) of textile products, eco-efficiency and definition of best available techniques (BAT) of textile processing. J. Clean. Prod. 2007, 15, 1259-1270. [CrossRef]

33. Lakhal, S.Y.; Sidib é, H.; H'Mida, S. Comparing conventional and certified organic cotton supply chains: The case of Mali. Int. J. Agric. Resour. Gov. Ecol. 2008, 7, 243-255. [CrossRef]

34. Forman, M.; Jorgensen, M.S. Organising environmental supply chain management-Experience from a sector with frequent product shifts and complex product chains: The case of the Danish textile sector. Greener Manag. Int. 2004, 45, 43-62.

35. Niinimäki, J.P. Does collateral fuel moral hazard in banking? J. Bank. Finance 2009, 33, 514-521. [CrossRef]

36. Faisal, M.N. Sustainable supply chains: A study of interaction among the enablers. Bus. Process Manag. J. 2010, 16, 508-529. [CrossRef]

37. Kim, A.J.; Ko, E. Do social media marketing activities enhance customer equity? An empirical study of luxury fashion brand. J. Bus. Res. 2012, 65, 1480-1486. [CrossRef]

38. Schrettle, S.; Hinz, A.; Scherrer-Rathje, M.; Friedli, T. Turning sustainability into action: Explaining firms' sustainability efforts and their impact on firm performance. Int. J. Prod. Econ. 2014, 147, 73-84. [CrossRef]

39. Rieple, A.; Singh, R. A value chain analysis of the organic cotton industry: The case of UK retailers and Indian suppliers. Ecol. Econ. 2010, 69, 2292-2302. [CrossRef]

40. Christopher, M.; Juttner, U.; Baker, S. Demand chain management: Integrating marketing and supply chain management. Ind. Market. Manag. 2007, 36, 377-392.

41. Lusch, R.; Vargo, S.; O’Brien, M. Competing through service: Insights from service-dominant logic. J. Retail. 2007, 83, 5-18.

42. Vargo, S.; Stephen, L.; Robert, F.L. Evolving to a New Dominant Logic for Marketing. J. Market. 2004, 68, 1-17. [CrossRef]

43. Kito, T.; Fujita, K.; Takenaka, T.; Ueda, K. Multi-Agent Market Modelling Based on Analysis of Consumer Lifestyles. In Proceedings of the 41st CIRP Conference on Manufacturing Systems, Manufacturing Systems and Technologies for the New Frontier, London, UK, 26-28 May 2007; Springer: London, UK; pp. 507-510.

44. Ueda, K.; Kito, T.; Takenaka, T. Modellling of Value Creation Based on Emergent Synthesis. CIRP Ann. Manuf. Technol. 2008, 57, 473-476. [CrossRef]

45. Jong, A.D.; De Ruyter, K. Adaptive versus proactive behavior in service recovery: The role of self-managing teams. Decis. Sci. 2004, 35, 457-491. [CrossRef]

46. Leischnig, A.; Kasper-Brauer, K. Employee adaptive behavior in service enactments. J. Bus. Res. 2015, 68, 273-280. [CrossRef]

47. Lamming, R.; Harland, C.; Zheng, J.; Johnsen, T. An initial classification of supply networks. Int. J. Oper. Prod. Manag. 2000, 6, 675-694. [CrossRef]

48. Christopher, M.; Towill, D.R. Developing market specific SC strategies. Int. J. Logist. Manag. 2002, 31, 1-14. [CrossRef]

49. Vitasek, K.L.; Manrodt, K.B.; Kelly, M. Solving the Supply-Demand Mismatch. Supply Chain Manag. Rev. 2003, 7, 58-64.

50. Caniato, F.; Caridi, M.; Castelli, C.M.; Golini, R.A. Contingency approach for SC strategy in the Italian luxury industry: Do consolidated modells fit? Int. J. Prod. Econ. 2009, 120, 176-189. [CrossRef]

51. Childerhouse, P.; Aitken, J.; Towill, D.R. Analysis and design of focused demand chains. J. Oper. Manag. 2002, 20, 675-689. [CrossRef]

52. Devinney, T.; Auger, P.; Eckhardt, G.M. Values vs. Value. Strategy + Business. 2011. Available online: http:/ / www.strategy-business.com/article/11103?gko=03d29 (accessed on 22 February 2011).

53. Auger, P.; Devinney, T.M.; Louviere, J.J.; Burke, P.F. Do social product features have value to consumers? Int. J. Res. Market. 2008, 25, 183-191. [CrossRef]

54. Brun, A.; Castelli, C. Supply chain strategy in the fashion industry: Developing a portfolio mode depending on product, retail channel and brand. Int. J. Prod. Econ. 2008, 116, 169-181. [CrossRef] 
55. Perrini, F.; Castaldo, S.; Misani, N.; Tencati, A. The impact of corporate social responsibility associations on trust in organic products marketed by mainstream retailers: A study of Italian consumers. Bus. Strategy Environ. 2010, 19, 512-526. [CrossRef]

56. Lee, C.K.M.; Lam, J.S.L. Managing reverse logistics to enhance sustainability of industrial marketing. Ind. Market. Manag. 2012, 41, 589-598.

57. Dubois, A.; Araujo, L. Case research in purchasing and supply management: Opportunities and challenges. J. Purch. Supply Manag. 2007, 13, 170-181. [CrossRef]

58. Hung Lau, K.; Wang, Y. Reverse logistics in the electronic industry of China: A case study. Supply Chain Manag. Int. J. 2009, 14, 447-465. [CrossRef]

59. Conti, S. 22.8\% Increase in Stella Mccartney Sales for Fiscal-Year 2012: Stella McCartney Profits Up $19 \%$. Available online: http:/ / www.vogue.co.uk/article/stella-mccartney-2012-profits-increase-by-19-per-cent (accessed on 27 September 2013).

60. Conti, S. Stella McCartney Profits Climb 4.8\% in 2013. WWD. Available online: http://wwd.com/ business-news/financial/stella-mccartney-profits-climb-48-in-2013-7948956/?module=more_on (accessed on 8 October 2014).

61. Cartner-Morley, J. G2: The Luxury of Having the Parents I Had Was that If All This Goes Horribly Wrong, I'll Be All Right. The Guardian. Available online: http://cartner6.rssing.com/chan-5444486/all_p4.html (accessed on 5 October 2009).

62. Ings-Chambers, E. Say Goodbye to Washed-Out Lycra. Financial Times. Available online: http://search.ft. com/search?queryText=Say+goodbye+to+washed-out+Lycra (accessed on 29 January 2005).

63. Mayring, P. Qualitative Content Analysis. Forum Qualitative Sozialforschung/Forum: Qualitative Social Research. Available online: http:/ / www.qualitative-research.net/index.php/fqs/article/view/1089/2385 (accessed on 24 January 2000).

64. Bergström, R. Hennes Signs Up McCartney. Financial Times. Available online: http://search.ft.com/search? queryText=Hennes+signs+up+McCartney (accessed on 12 May 2005).

65. Carreon, B. Stella McCartney on Receiving an OBE, Her Critics, and Being a Woman Designing for Women. Forbes. Available online: https://www.forbes.com/sites/bluecarreon/2013/05/24/stella-mccartneyon-receiving-an-obe-her-critics-and-being-a-woman-designing-for-women/\#33165e0356b5 (accessed on 24 May 2013).

(C) 2017 by the authors. Licensee MDPI, Basel, Switzerland. This article is an open access article distributed under the terms and conditions of the Creative Commons Attribution (CC BY) license (http:/ / creativecommons.org/licenses/by/4.0/). 